\title{
A case study of trainee teachers' mental models of history teaching before and after an initial history teaching professional development course
}

\author{
Charles Adabo Oppong* - University of Cape Coast, Ghana
}

\begin{abstract}
The study compares 28 third-year University of Cape Coast trainee teachers' perceptions and mental models of history teaching before and after an initial history teaching professional development course - the Methods of Teaching History Course - to prepare them to teach history. The History Course was an intervention strategy built around episodic memory theory. The research questions were: Do trainees' perceptions (mental models) of history teaching remain the same or change during the History Course? If they change, how and why? Research involved all 28 trainees before and after they took the course through the use of a questionnaire and vignettes, plus a post-course interview of 12 of the trainees. The researcher used a deductive approach to analyse data about three aspects of the trainees' history teaching mental models: pedagogy, teaching styles as illustrated through classroom organization, and how students learn history. Findings revealed a marked difference between the trainees' pre- and post-course mental models of what school history is and how it should be taught. The trainees' pre-course mental models changed as a result of the knowledge and understanding they acquired during the History Course. A major finding was that such professional development courses need fully to take account of trainees' pre-course conceptions that shape their mental models of history teaching.
\end{abstract}

Keywords: constructivist theory; episodic memory theory; Ghana; mental models; methods course; pre-service teachers; teacher professional development

\section{Introduction}

Ghanaian teacher trainees do not come to the history classroom as tabulae rasae, eagerly awaiting teacher educators to shape how they teach the subject. They have preconceptions of history teaching, attitudes towards it, expectations about it and even fixed views on how it should be taught (Oppong, 2014). Often there is a major gap between trainees' expectations and those of history teacher educators and teachers in charge of their training and overall professional development, who usually expect the trainees to view history as a discipline that requires particular analytical skills. However, most trainees believe that history is a body of given factual information (Joseph, 2011).

A major factor for this is that the majority of history teacher trainees have little or no background in the study of history. For decades in Ghana, the teaching of history has had a marginal presence in the school curriculum. This is largely because history has not been included in the prescribed school curriculum, as it is in most other jurisdictions (Bradley Commission, 1988). While some Ghanaian students may obtain knowledge of 
history from educational films and selected television programmes, the only exposure to the subject they are likely to have in school is in social studies lessons (Joseph, 2011). Oppong (2012) affirmed social studies as the major source of history trainee teacher acquisition of historical knowledge, particularly at the junior high school level. Through this experience trainees therefore form lasting impressions about and understanding of history as a discipline and its teaching (Joseph, 2011). Loewen (2007) found that students perceive social studies history as boring and irrelevant. Understandably, a majority dislike history as a school subject (Cobbold and Oppong, 2010; DiCamillo, 2010; Loewen, 2007; Russell, 2012).

Teacher-centred didactic teaching involving the transmission of factual knowledge is the dominant pattern of social studies history pedagogy (DiCamillo, 2010), an approach that uses lectures, textbooks, end-of-chapter review questions and multiple-choice tests (DiCamillo, 2010; Nowicki and Meehan, 1996; Schell and Fisher, 2007; Young, 1994). As Haydn et al. (2001) indicate, history classes can be a nightmare for some students because, all too often, uninspiring teachers reduce the subject to tedious lists for memorization of dates, facts, figures, the location of historical events and names, including Ghana's rulers and the periods of their reigns (Joseph, 2003; Darkoa, 2015; Haydn et al., 2001).

In higher education, history teaching is largely the same. Lecturers in Ghana's universities and colleges still emphasize the learning of a corpus of historical knowledge, rather than the critical analysis and interpretation of historical sources and evidence, and drawing conclusions from them (Oppong et al., 2017). Consequently, based upon their own experiences of history in schools, and even higher education, trainees have developed negative and limited preconceptions about how history can be taught.

Woolcock et al. (2011: 72) argue that history involves 'acquiring the entire sensibility about how to compile, assess and interpret evidence, substantiate causal claims, and understand complex (often interdependent) processes'. Trainee teacher pre-course models of history teaching are diametrically different to this enquiry- and process-driven model, which gives students responsibility for actively learning history that develops the wide range of critical thinking skills that thinking historically involves. An impoverished, didactic transmission model of history teaching is synonymous with trainees' preconceptions that history is a body of factual knowledge - a dry, tedious and obscurantist subject (Herbst, 1962).

Most trainees may begin the History Course with these perceptions about the teaching of history. Do these perceptions (mental models) of history teaching remain or change during the course? If they change, how and why do they do so? It is these questions that this study seeks to answer. The issue is that there are conflicting conceptual paradigms that teachers need to bring together in order to establish a foundation for a solid scholarly approach to history teaching. Careful consideration must be given to trainees' views about the subject of history itself, if the History Course is to be successful in changing them. This can only be achieved if an attempt is first made to identify the different conceptual frameworks and conceptions that exist in trainees' thinking about history teaching before participating in the History Course.

Once trainees begin teacher education programmes, they filter new theories on the basis of their preformed conceptions (Eick and Reed, 2002). Therefore, investigating prior perceptions that contribute to their professional development, and the extent to which they are combined through their underlying conceptualizations and experiences, is essential for teacher professional development. As previously demonstrated (Lasley, 1980), if trainees' perceptions are not examined, they will not be open to current research-based practices of teaching. Again, this is critical because 
research suggests that the educational perceptions of student-teachers play a pivotal role in their acquisition and interpretation of knowledge, and subsequent teaching behaviour (Calderhead and Robson, 1991; Clandinin and Connelly, 1986; Clark, 1988). As Pajares (1993) notes, unexplored beliefs may be responsible for the perpetuation of antiquated and ineffectual teaching practices or cultural reproduction. The present study, therefore, seeks to compare history teacher trainees' mental models before and after the History Course. This will provide an opportunity to examine the perceptions that prospective history teachers have before the History Course, as well as those that they acquire during it. Identifying the difference between trainees' initial and postHistory Course perceptions could be a factor in helping improve the History Course.

\section{Mental models}

A mental model is a representation (schema), an abstraction of an external reality, hypothesized to play a major role in cognition, reasoning and decision-making:

When humans perceive the world, vision yields a mental model of what things are where in the scene in front of them. Likewise, when they understand a description of the world, they can construct a similar, albeit less rich, representation - a mental model of the world based on the meaning of the description and on their knowledge. The current theory of mental models (the 'model' theory, for short) makes three main assumptions. First, each mental model represents what is common to a distinct set of possibilities. So, you have two mental models based on Micawber's advice: one in which you spend less than your income, and the other in which you spend more. (What happens when your expenditure equals your income is a matter that Micawber did not address.) Second, mental models are iconic insofar as they can be. This concept, which is due to the 19th century logician Peirce, means that the structure of a representation corresponds to the structure of what it represents. Third, mental models of descriptions represent what is true at the expense of what is false. (Johnson-Laird, 2010: 2)

Thus, a mental model represents a person's meta-cognitive thought process about how something works in the real world. It is a representation of the surrounding world, the relationships between its various parts, and a person's intuitive perception about his or her own acts and their consequences. According to Norman (1983), mental models provide a belief system, reflecting beliefs acquired through observation, instruction or inference. These acquired belief systems become a person's perception of a particular thing observed or received through instruction. What trainees are given in the form of instruction, or have observed, will form their perception of a particular object or reality. In the literature, the term 'mental model' is often used interchangeably with 'perception'. In this study, the terms are used synonymously, since they mean essentially the same thing.

\section{Theoretical framework}

This study is grounded in the episodic memory theory. Episodic memory is a neurocognitive (brain/mind) system, uniquely different from other memory systems that enable human beings to remember past experiences (Tulving, 1983). The theory represents an effort to formulate a set of interrelated ideas about memory that are 
internally consistent and reasonably closely tied to the basic empirical facts about memory (Hassabis and Maguire, 2007). The theory provides explanation that our everyday personal experiences are an essential ingredient in shaping how we perceive ourselves. Curricular experiences, therefore, influence trainees' perception of current and future events. The theory allows us to represent past experiences, and flexibly to employ these representations in the service of current and future happenings. The past experiences form the beliefs that people share and connect to current events. Nespor (1987) argues that beliefs draw their power from previous events that influence the comprehension of subsequent events. Nespor (ibid.) explains that beliefs are strong predictors of behaviours and determine how individuals organize and define tasks.

The implications of the episodic memory theory are important to this study. The past experiences that determine belief systems are believed to influence and frame how one learns, and how one uses what is taught (Thomas et al., 2001). These beliefs later serve as a template or mental model (perception) for one's own teaching practices. As Calderhead and Robson (1991) and Clark (1988) note, trainees' educational beliefs significantly influence the perceptions and judgements they make about their own and others' teaching. This implies that how history teacher trainees perceive history teaching could be influenced by their past experiences of how history has been taught in their primary and secondary schools. As Nespor (1987) points out, teachers' classroom practices have roots in their own experiences of schooling, particularly in their previous interaction with their own teachers, resulting in certain perceptions, values and expectations of teaching. Lortie (1975: 65) explains the reason behind this:

Teaching is unusual in that those who decide to enter it have had exceptional opportunity to observe members of the occupation at work: unlike most occupations today, the activities of teachers are not shielded from youngsters ... Those planning to teach form definite ideas about the nature of the role.

This suggests that trainees and untrained early career teachers bring with them into teaching a teaching schema, possibly formed over years of experience of schooling, and sometimes from their own prior teaching experiences (Akyeampong and Stephens, 2002). This schema then becomes the basis for the trainee teacher of what teaching is 'supposed' to be (Bullough et al., 1991). Pre-service trainees are, therefore, likely to retrieve information from their episodic memory (remembering or conscious recollection) to establish mental models (perceptions) of how history is taught today.

In the school system, Barnes (1992) further notes that since one has a set of interconnected expectations before entering the classroom, one's mental model is organized in 'frames' or clustered sets of expectations. He explains that teachers' professional frames are both individually and socially constructed - shaped by experiences, as well as expectations and values, from the outside as well as the inside. Barnes's (1992) explanation gives credence to Crow's earlier report (1987) that teacher education candidates begin preparation programmes with a well-established teacherrole-identity from what they have either observed or experienced.

These teacher-role-identities, observed or experienced, could be a teachercentred transmission or student-centred constructivist approach, reflecting behaviourist and constructivist theories respectively. The role of the behaviourist teacher is to transmit and mediate learning materials to trainees in the form of lectures, reflecting students' roles as the receivers of information from the 'all-knowing' classroom teacher. The constructivist paradigm, on the other hand, argues that the role of the teacher is to assist learners to apply the appropriate learning strategies to ideas, concepts and 
principles, with learners being actively engaged in the learning process with some responsibility for their own learning. History teacher trainees are, therefore, likely to assimilate History Course learning strategies in their episodic memories that both influence their teacher-role-identities and form their mental models of how history is taught.

\section{Research methodology}

\section{Sample size and the constructivist intervention strategy}

The study involved all 28 third-year history teacher trainees at the University of Cape Coast who took the History Methods Course as part of their programme in the first semester of the third year. The course was based on a constructivist theory designed to challenge and alter trainees' preconceptions of history and its teaching. The course focused on the development of the skills, pedagogic strategies and activities needed to prepare effective types of history teaching lesson plans, including the role of assessment - measurement and evaluation - as a major factor.

The History Course was an intervention strategy, with constructivist theory as its pedagogic philosophy, involving active student participation in their learning. Here the teacher is a guide, facilitator and co-explorer who encourages learners to question, challenge and formulate their own opinions and conclusions. One major assumption of constructivist epistemology is that individuals create or construct their own knowledge through the interaction of what they already know and believe with the ideas, events and activities with which the course brings them into contact (Cannella and Reiff, 1994). Learning activities in constructivist classrooms, therefore, are characterized by active involvement in tasks, enquiry, problem-solving and collaborative learning.

Constructivist epistemology recognizes the value of student perceptions, and makes allowances for expectation gaps that may occur between the different roles of teachers and learners. Teachers who embrace this world-view, therefore, shift away from a teacher-centred classroom to a more student-centred environment where the student becomes the primary focus in the teaching and learning process. As such, the constructivist theory provides that teacher trainees' involvement in lesson delivery helps change trainees' perceptions about classroom teaching. In the lecture room, the trainees can take control of the learning situation, such as in problem-based learning. As trainees engage themselves in instruction, they develop an understanding of the problem, grasp the relevance of the topic, and construct knowledge through their experiences. Meaningful, focused activities result in high-level thinking, conceptualization, problem-solving, creative activities and understanding for trainees to develop their own identities as history teachers. It was hoped that, through the History Course, constructivism would change trainees' prior perceptions of history teaching from being teacher- to student-centred.

\section{Data collection and instrumentation}

Data was collected in the 2016/17 academic year before and after trainees took the History Course, using a questionnaire, vignettes and a post-course interview. The trainees were given the same questionnaire before and at the end of the course. This was to find out whether or not trainees' perceptions and mental models of how history is taught had changed during the course. The trainees were not notified that they would answer the same questions at the end of the course. This approach ensured reliability, because the awareness of the trainees would have influenced their responses. 
Data was also collected pre- and post-course with the use of a vignette involving drawings (see box), and post-course using a structured interview. There were three pictorial items in the vignette, which were, like the questionnaire, designed to explore the pre- and post-course mental models of trainees. The vignettes were visual, iconic representations of their mental models. The first item asked trainees to 'Draw a picture of yourself as a history teacher at work'. The second picture requested trainees to explain what the history teacher - that is, himself or herself - was doing. The third drawing required them to show what the trainees and students would be doing in the classroom. A follow-up interview was conducted using 12 student-teachers out of the 28 who initially responded to the vignette. The researcher randomly selected the 12 from the 28 trainees. The interview was aimed to discover the reasons why the trainees' conceptions and mental models had changed during the course.

\section{Research instrument (vignette)}

1. Draw a picture of yourself as a history teacher at work.

2. What is the history teacher doing?

3. What are the history trainee teachers doing?

\section{Data analysis}

A deductive approach was used to qualitatively analyse the research data. Three themes formed the core around which to group data: (1) the teachers' activities; (2) their classroom positions/teaching style; and (3) student activities/learning. The vignette's picture section divided into two subsections that focused on the teacher's pedagogy - for example, lecturing, using instructional materials and demonstrating - and the teacher's classroom position, that is, teaching style - the location of the teacher in the classroom. The drawings were further categorized into two fairly distinct groups - teacher-centred and student-centred. The teacher-centred group also divided into two subsections that focused on the activity of the teacher as the fulcrum around which teaching revolved - for example, demonstrating, lecturing, using teaching resources and technology - and the teacher's classroom position. The third section focused on the activities of students - for example, passively receiving information, responding to the teacher and their classroom location - that is, where they were sitting or standing. Additionally, the qualitative data was quantified to determine the number of trainees' particular responses.

\section{Limitations}

The sample consisted of 28 history teacher trainees. However, for interview purposes, 12 were selected randomly from the 28 . It can be argued that the group of trainees who were not interviewed may have had different mental models from those who were interviewed. The fact that there were changes in the 12 interviewed trainees' mental models of history teaching before and after the course does not automatically mean that all course members experienced such changes, although there is no evidence that suggests that they did not, as the 12 trainees' mental models were similar to the responses of the other 16 to the questionnaire and in their vignettes. While the findings from this study indicated a positive response to the course's constructivist theory of teaching history and its application, there are no follow-up research studies of previous History Course trainees to discover whether or not they had implemented the course's constructivist model of history teaching. 


\section{Findings}

\section{A history teacher at work: Trainee teachers' drawings}

The majority of the pre-course pictures that the trainees drew of themselves as history teachers ( $n=26,92$ per cent) suggested their pedagogy would be didactic, that is, speaking to the class (see Figures 1 and 2). Two of the pictures (7 per cent) showed one of them as a teacher writing on the board and the other as a teacher reading from a book to the students, both typical of the didactic, transmission model of teaching.
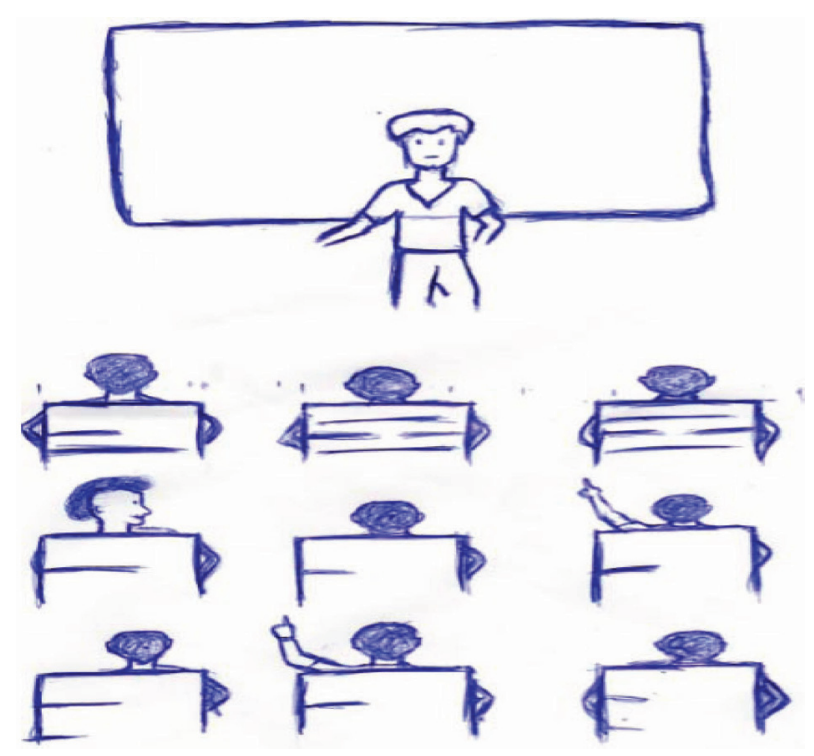

Figure 1: Pre-instructional trainee teacher's drawing of teacher facing the class

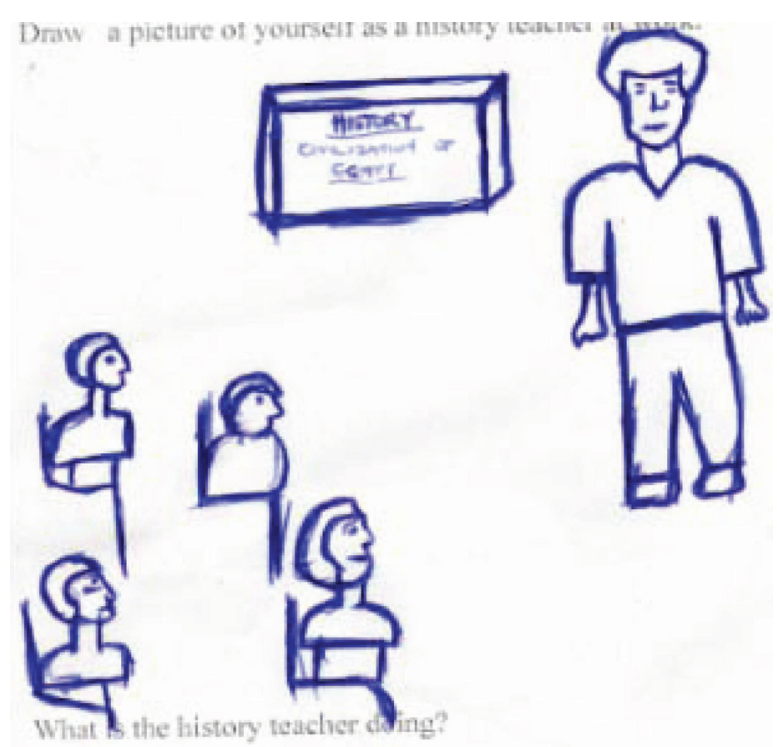

Figure 2: Pre-instructional trainee teacher's drawing suggesting trainee teachers are sitting in a circle facing the teacher 
In most of the pre-course pictures, trainees placed themselves as history teachers in front of the class with their mouths open, that is, addressing the students. As teachers, the trainees could be transmitting information in the form of a lecture. However, they could also have been asking questions, answering questions, presenting information on the topic being taught or explaining, all typical elements in their mental models of didactic teaching.

All of the classroom illustrations fall into two fairly distinct groups - teachercentred and student-centred. The teacher-centred illustrations of themselves as teachers at the start of the course usually placed the teacher in front of the class. The teacher is often positioned in front of a chalkboard or a chart that supports his or her lesson presentation. Classroom organization frequently indicates the traditional placement of desks or chairs in rows. These images fit with the teacher-centred didactic, the transmission model in which the teacher organizes, presents and mediates given historical knowledge. Analysis of the pictures drawn after the course revealed two contrasting views of themselves as teachers in the classroom. The first category showed that they were either within circles of students seated, or students were standing with the teacher in front of the class. The second category of pictures showed them as teachers sitting behind a set of teaching resources, probably artefacts, in front of the class (see Figures 3 and 4).

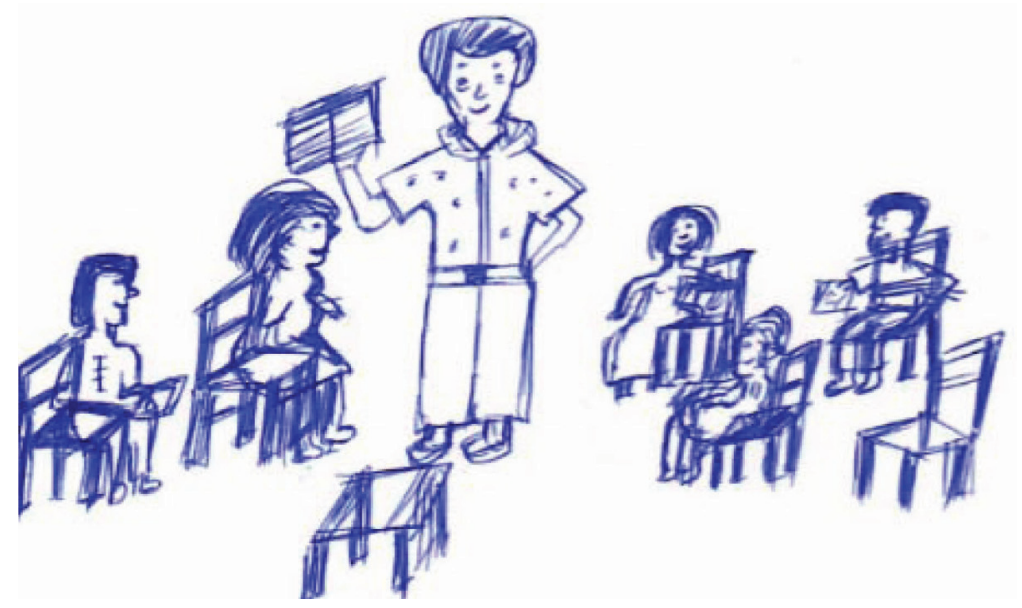

Figure 3: Post-instructional trainee teacher's drawing suggesting she is interacting with a small group

The first category of post-course pictures is evidence that as teachers they were interacting with student groups in the class. The second category suggests that they were using teaching resources to support their teaching. The two categories of pictures indicate student-centred teaching activities with teacher involvement as guide, supporter and facilitator. In the student-centred pictures, it is sometimes difficult to identify the teacher, who is often labelled with an arrow or series of arrows to indicate movement between different groups. The classroom organization usually includes extra tables for resources in addition to the desks and chairs normal in teacher-centred transmission lessons. These images reflect student-centred teaching in the constructivist paradigm of learning that encourages teacher-facilitated enquiry, questioning, discussion and collaborative working in pairs or small groups. In the pictures of history teaching before the History Course, the images were of teachercentred pedagogy and interaction with students. The post-course images portrayed a 
student-centred constructivist classroom. The findings suggest that the mental models of the trainees have changed in terms of how they view history teachers' pedagogy, classroom roles and teaching styles.

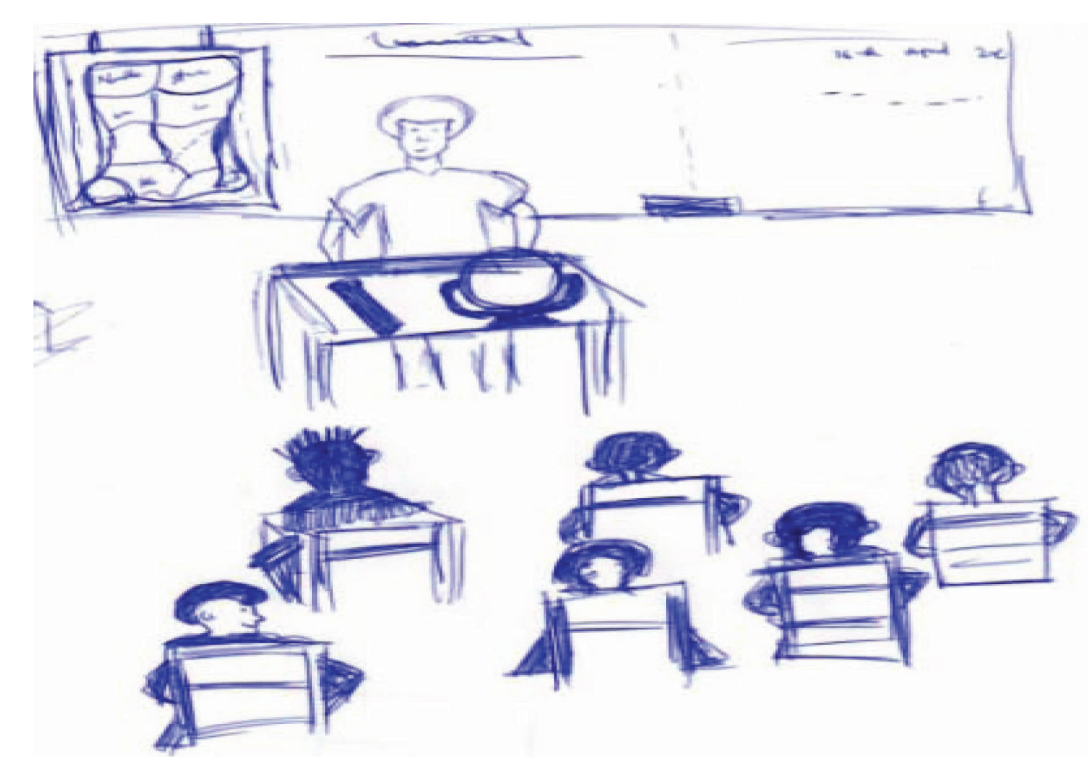

Figure 4: Post-intervention trainee teacher's drawing suggesting teacher is presenting instructional aids to the class

\section{History teachers' pedagogy}

The majority (26-96 per cent) of the trainees' pre-course questionnaire responses indicated that the history teachers were talking to the class: 22 (78.6 per cent) wrote that the teachers were lecturing or reading from the history textbook; 4 said teachers were providing explanation to the students; there were no comments from 2 trainees. Examples of written responses from the 22 students included: 'the teacher is explaining the concept of civilization to students', and 'the history teacher is lecturing students on the importance of studying history'. The other 4 trainees (21.4 per cent) who responded made comments including: 'the teacher is writing notes on the board for students to copy', and 'the history teacher is reading from the history textbook for students'. These responses indicate that trainees viewed such history teaching as non-interactive. In many situations, the history teachers were described as addressing or lecturing to the class, while occasionally they used the history textbook. The trainees noted that students were uninvolved in the lessons.

Analysis of the post-course questionnaires revealed three main findings about the trainees' conceptions of history teaching that they had developed during the course. A majority (18-64.3 per cent) wrote that the teachers were listening to group discussions in the class. The following statements were noted: 'the teacher is observing students as they discuss what they have been assigned to', and 'the teacher was contributing to students' group discussions'. Eight (28.6 per cent) other trainees also stated that the teachers were using teaching resources or equipment in teaching the lesson: 'the teacher is using audio equipment to teach his lesson', and 'the students are observing some pictures on the computer with the teacher'. Finally, 2 trainees $(7.1$ per cent) indicated that the students in front of the class were enacting specific historical events.

The trainee teachers' explanations communicate two key understandings. First, they highlight the active involvement of the students in the lessons. Second, 
they discuss positively the use of teaching resources and equipment such as artefacts and pictures in constructivist teaching, in contrast to the over-reliance on the history textbook and the lecture in the transmission model. Post-course questionnaire analysis indicates that the trainees had understood that history teaching can be interactive through student involvement, as opposed to the passive assimilation of historical information. This is in stark contrast to the trainees' pre-course observations about non-interactive transmission history pedagogy that failed to stimulate student interest and enjoyment.

Similarly, the post-course findings corroborate the trainees' post-course visual representation of history teaching. Their pre-course drawings showed teacher-centred domination of the classroom, in contrast to the post-course illustrations with their focus on student-centred interaction between teacher and students. This suggests that there is a difference between the mental models of the trainees in the two situations, based on the responses elicited from the two separate results. The interviewees provided reasons for changes in perception. This change is important because it helps to highlight the positive image of history teaching.

\section{History teacher trainee perceptions}

The trainees' pre-History Course questionnaire answers confirmed their pre-course pictorial perception of the transmission model of Ghanaian history teaching. The majority of statements said that students were passive in history lessons:

- 'the students are listening to what the teacher is saying'

- 'the students are listening to what the teacher is reading from the history textbook'

- 'the students are writing what is on the board into their notebooks'.

Teachers dominated such history lessons - their students were passive, with little or no active involvement. The teacher-centred transmission pedagogy has a negative effect, as the teacher tacitly suggests that the students have little or nothing to contribute to their learning.

There was unanimity in trainees' responses after the History Course about differences between their pre-course teacher-centred transmission and their postcourse student-centred constructivist history teaching models. Trainees wrote that in the post-course mental model, students had full involvement in constructing their historical knowledge and understanding through an interactive pedagogy:

- 'the students are contributing to the lesson through the group discussion'

- 'the students are participating in the class as they demonstrated what they have read'

- 'the students are observing what is being shown to them by the teacher'.

\section{Reasons for the change in mental models}

Analysis of the before and after History Course questionnaires, and of trainees' pictorial representation of history teaching, indicated that their mental models of history teaching had changed during the course. This demanded further investigation to explain why. Accordingly, an interview was conducted with 12 trainees. The key question invited them to explain the reasons why their views about how history is taught had altered by the end of the course. This enabled the researcher to gain insights into their post-course mental models. The trainees' responses clustered around two 
reasons. The first was the pedagogy of the History Course, with its focus on studentcentred approaches. Salient responses were:

- 'the teacher involved us [trainees] in the lessons throughout the course'

- 'the teacher illustrated to us how students could be involved in history teaching'

- 'there was class involvement during the lessons in the course ... using topical issues in the history syllabus'

- 'active participation in the course explains my reason because I realized you can teach history by involving students'.

The second reason for trainees' new mental models of history teaching was the pedagogic content of the History Course. Illustrative quotations are:

- '.. the knowledge I acquired during the course changed my understanding of how history could be taught. A lot of methods that could be used in teaching history were discussed in the course of the class, so the view that only the lecture method could be used in teaching history is no more valid.'

- '.. in the [teaching] method class, we were exposed to a plethora of interactive methods of teaching that could be used in the teaching of history. Not only the exposure, but also, we were taken through how to use these methods in teaching history that will make history lessons interesting.'

The research findings strongly indicate that courses on pedagogy are a vital component of the history education curriculum. The History Course not only equipped trainees with pedagogical knowledge and expertise about teaching history, but also provided them with a positive perception of how the subject could be taught in schools. The trainees also further explained that what shaped their perceptions was the contrast with how history had been taught in their schools:

- '... how history was taught by my teacher in senior high school gave me the impression that it is only the lecture method that could be used in teaching history'

- 'I thought history teaching is about reading from the textbook because that was how history was taught throughout the three years in senior high school'.

These short trainee narratives help confirm the thinking behind the episodic memory theory that underpinned the History Course. The past experiences of the trainees influenced and framed how they learned history and used what was taught (Thomas et al., 2001). These episodic memories served as a mental model (or perception) about how history is taught. As Calderhead and Robson (1991) and Clark (1988) note, trainees' educational beliefs significantly influence the perceptions and judgements they make about their own and others' teaching. This implies that trainees' memories of their school history teaching influenced perceptions of history teaching before the History Course. The trainees retrieved information from their episodic memory (remembering or conscious recollection) to establish their pre-course mental models of history teaching.

\section{Discussion}

Analysis and review of the research data were aimed at understanding the perceptions and mental models of history teaching of the trainees. Findings and reflection on the study's three themes of trainees' perceptions of history teachers' pedagogy, teachers' classroom organization, and how students learn history illuminated trainees' 
perceptions and mental models before and after the History Course, and how and why they had radically changed.

Concerning the first theme, perception of history teachers, it required trainees to draw a picture of a history teacher at work. The drawings suggested the teachers taught using the transmission lecture method and history textbooks. The second theme, which required trainees to show what the history teacher was doing in the classroom, confirmed the transmission model, in which teachers were addressing the class or reading from the history textbook.

The pre- and post-course questionnaire and post-course interview data about the trainees' pre-course perceptions and mental models of history teaching substantiate similar findings of trainee perceptions of how history is taught. Trainees had seen history teaching pedagogy as being teacher-centred, with the predominant use of lectures, textbooks, end-of-chapter review questions and multiple-choice tests (DiCamillo, 2010; Nowicki and Meehan, 1996; Oppong, 2009; Schell and Fisher, 2007; Young, 1994).

Conversely, the mental models of trainees on the History Course changed to a constructivist building of historical knowledge and understanding:

- Analysis of the pictures of constructivist history lessons showed trainees interacting with students in groups, using historical evidence such as artefacts, and engaging in role play. These observations alone suggest trainees' appreciation of interactive approaches to teaching history.

- Trainees' explanations of how teachers taught in these course sessions concurred with analysis of the pictures. They explained that the history teachers were listening to student discussions in groups, using historical sources in their teaching and supervising student role play. These explanations indicate that the classes were student- not teacher-centred. Student involvement meant they were involved in the processes of constructing their own history, that is, 'doing history'. To trainees, this made meaningful a constructivist approach to learning history.

- Furthermore, the responses on the third theme, how students were taught, succinctly clarified the constructivist point, for example, the central idea of student participation and involvement in their learning.

Pre-service teachers' mental models (perceptions) about how history is taught had radically changed during the course. Their mental models now perceived that history teaching could be student-centred and interactive, with students making use of teacher guidance and support to construct historical understanding, as opposed to passively assimilating a body of knowledge moderated or transmitted by teachers. This conclusion challenges the prevailing teaching orthodoxy that traditional transmission methods are the way in which to teach history (Haydn et al., 2001).

The research findings about the History Course further suggest that trainees' experiences and memories of history teaching in secondary school shaped their precourse mental models of teaching. DiCamillo (2010), Schell and Fisher (2007) and Young (1994) established that history teacher trainees' perception of how history is taught is formed in secondary/high school. Additionally, trainees' pre-course mental models and perceptions highly correlate with their specific, intense memories of their own history learning experiences in primary school, secondary school and university (Oppong et al., 2017; Darkoa, 2015). Frequent references to specific room arrangements suggest trainees' memories of history classrooms affect their thinking (Barnes, 1992). As Crow's (1987) report suggested previously, teacher education students have a 
well-established teacher-role-identity before starting their higher education (tertiary level) programmes.

It is reassuring that this study has identified the importance of pedagogical preparation in the training of history teachers. Recent research on teacher education has shown a positive connection between teachers' development of their pedagogic content knowledge and their classroom performance and impact on student learning. These studies indicate that the lack of a thorough understanding of how specific subjects are taught can impede good teaching (Darling-Hammond, 2000; Goldhaber and Brewer, 2000; Guyton and Farokhi, 1987; Monk, 1994). Similarly, research on trainees' courses (for example, theoretical foundations of education, psychology of education, instructional methods and classroom management) have positive effects on teacher performance and, ultimately, trainees' professional development (Adams and Krockover, 1997; Darling-Hammond, 2000; Fetler, 1999; Grossman, 1989; Hawk et al., 1985).

The research findings were encouraging, in that trainees' exposure to, and active experience of, a range of stimulating, interactive pedagogic approaches to planning and teaching history lessons not only erased negative perceptions of how the subject is taught, but also made history teaching more effective through developing constructivist high-level skills, processes and syntactic concepts. History professional development courses focusing on the pedagogic content knowledge of history are important for trainees who will teach history. The trainees noted that their active involvement in their lessons changed their perception about how history can be taught, as Lortie (1977) indicated.

Trainees' involvement in the reconstruction of knowledge in the classroom, and its subsequent effect of changing their perception, confirms the constructivist theory used for the study. Lortie (1975) calls this 'apprenticeship of observation', because the pre-service teachers' perception changed under the apprenticeship of the lecturer. As indicated earlier, the issue of content also came up strongly as a major reason underpinning the change. Lortie (1977) explains that individuals who love certain topics of a course are influenced by that enjoyment, and this affects their views. The findings of this study confirm those of previous studies.

The trainees' pre-entry mental models of history teaching, with their straightforward transmission teaching pattern, had not prepared them for the complexity, variety and sophistication of the constructivist approach and the interactive pedagogic activities of the History Course. Understandably, the trainees assigned great importance to the pedagogical training, an observation that contradicts earlier studies that suggested that trainees' perceptions tend not to change over time (Doolittle et al., 1993; Griffin, 1986; Tabachnick and Zeichner, 1984). Likewise, this study challenges research on pre-service teachers' perceptions that indicate that initial teacher professional development courses do little to alter the perceptions that trainees develop about teaching (Bird et al., 1993; Doolittle et al., 1993; Doyle, 1990; Lerman, 1997).

Teacher educators need to be aware that the findings of research on trainee teacher perceptions suggest that they tend to change over time. Therefore, understanding of the perceptions and belief structures of trainee teachers should help in improving the pedagogy of teachers. As Akyeampong and Stephens (2002) argue, the perceptions of pre-service teachers need to be made more explicit and given a voice in their professional development in order to promote reflection on the professional knowledge and classroom pedagogical practice at the heart of their understanding of teaching and teacher identity. 


\section{Conclusion, recommendation and contributions}

There was a fundamental difference between trainees' pre- and post-course mental models of how history is taught in schools. History pre-service trainees' preconceived mental models about how history is taught changed as a result of the knowledge and pedagogical experiences they received on the History Course. As such, several curricular changes that would address the issue of history teacher trainees' preconceived perceptions are necessary in history teacher education programmes. For example, institutions could consider incorporating history courses into their initial history teacher professional development courses that could help trainees consciously articulate their perceptions. Expressing, examining and reflecting upon their perceptions may contribute to a better understanding of how they view history teaching, as well as the skills they need to acquire to become effective history educators. As previously established (Lasley, 1980), if trainees' perceptions are not examined, they will not be open to current research-based practices of teaching.

This study has added to the minimal body of research and scholarship that has been conducted in the field of history education in Ghana, especially as compared to research and scholarship in other jurisdictions. Cobbold (2006) notes this significant point as he indicates that the worth of a study lies in extending not only the macro international body of knowledge but also the micro domestic literature in the field.

This paper also responds to the call for pedagogical renewal in history didactics. This is because the pedagogies that teacher educators and associated history teachers use largely determine trainees' perceptions and mental models of history teaching. In this regard, I offer the 'enabling constructive approach' of teaching history. In this approach, history teachers involved in training student teachers should make use of a constructivist pedagogy that involves trainees fully, for example, through role play and dramatization as well as classroom discussion and debate, historical investigations, brainstorming and the Socratic method. The findings of this study and related literature indicate a great concern, indeed a disturbing phenomenon, that history teachers rely on the passive, transmission method of teaching history. This study acknowledges the unique nature of history and, therefore, the need to ground the professional development of history teachers and their training in constructivist epistemology and a student-centred interactive history teaching pedagogy.

\section{Notes on the contributor}

Dr Charles Adabo Oppong is a senior lecturer in history education at the University of Cape Coast, Ghana. His areas of specialization include the history curriculum, history teaching in high school and preparation of history teachers.

\section{References}

Adams, P.E. and Krockover, G.H. (1997) 'Beginning science teacher cognition and its origins in the preservice secondary science teacher program'. Journal of Research in Science Teaching, $34(6), 633-53$.

Akyeampong, K. and Stephens, D. (2002) 'Exploring the backgrounds and shaping of beginning student teachers in Ghana: Toward greater contextualisation of teacher education'. International Journal of Educational Development, 22 (3-4), 261-74.

Barnes, D. (1992) 'The significance of teachers' frames for teaching'. In Russell, T. and Munby, H. (eds) Teachers and Teaching: From classroom to reflection. London: Falmer Press, 9-32.

Bird, T., Anderson, L.M., Sullivan, B.A. and Swidler, S.A. (1993) 'Pedagogical balancing acts: Attempts to influence prospective teachers' beliefs'. Teaching and Teacher Education, 9 (3), 253-67. 
Bradley Commission on History in Schools (1988) Building a History Curriculum: Guidelines for teaching history in schools. Washington, DC: Educational Excellence Framework.

Bullough, R.V., Knowles, J.G. and Crow, N.A. (1991) Emerging as a Teacher. London: Routledge.

Calderhead, J. and Robson, M. (1991) 'Images of teaching: Student teachers' early conceptions of classroom practice'. Teaching and Teacher Education, 7 (1), 1-8.

Cannella, G.S. and Reiff, J.C. (1994) 'Individual constructivist teacher education: Teachers as empowered learners'. Teacher Education Quarterly, 21 (3), 27-38.

Clandinin, D.J. and Connelly, F.M. (1986) 'Rhythms in teaching: The narrative study of teachers' personal practical knowledge of classrooms'. Teaching and Teacher Education, 2 (4), 377-87.

Clark, C.M. (1988) 'Asking the right questions about teacher preparation: Contributions of research on teacher thinking'. Educational Researcher, 17 (2), 5-12.

Cobbold, C. (2006) 'Teacher Retention in Ghana: Perceptions of policy and practice'. Unpublished PhD thesis, University of Melbourne.

Cobbold, C. and Oppong, A.C. (2010) 'Re-echoing the place of history in the curriculum'. International Journal of Educational Leadership, 3 (3), 89-96.

Crow, N.A. (1987) 'Preservice teachers' biography: A case study'. Paper presented at the Annual Meeting of the American Educational Research Association (AERA), Washington, DC, 20-24 April 1987.

Darkoa, A.L. (2015) History Trainee Teachers at the University of Cape Coast (UCC). Ghana: University of Cape Coast.

Darling-Hammond, L. (2000) 'Teacher quality and student achievement: A review of state policy evidence'. Education Policy Analysis Archives, 8 (1), 1-44. Online. https://epaa.asu.edu/ojs/ article/viewFile/392/515 (accessed 5 July 2018).

DiCamillo, L. (2010) 'Linking teaching for understanding to practice in a US history class'. Social Studies, 101 (1), 10-16.

Doolittle, S.A., Dodds, P. and Placek, J.H. (1993) 'Persistence of beliefs about teaching during formal training of preservice teachers'. Journal of Teaching in Physical Education, 12 (4), 355-65.

Doyle, W. (1990) 'Classroom knowledge as a foundation for teaching'. Teachers College Record, 91 (3), 347-60.

Eick, C.J. and Reed, C.J. (2002) 'What makes an inquiry-oriented science teacher? The influence of learning histories on student teacher role identity and practice'. Science Education, 86 (3), 401-16.

Fetler, M. (1999) 'High school staff characteristics and mathematics test results'. Education Policy Analysis Archives, 7 (9), 1-23. Online. https://epaa.asu.edu/ojs/article/viewFile/544/667 (accessed 5 July 2018).

Goldhaber, D.D. and Brewer, D.J. (2000) 'Does teacher certification matter? High school teacher certification status and student achievement'. Educational Evaluation and Policy Analysis, 22 (2), 129-45.

Griffin, G.A. (1986) 'Issues in student teaching: A review'. In Raths, J.D. and Katz, L.G. (eds) Advances in Teacher Education. Norwood, NJ: Ablex, 239-73.

Grossman, P.L. (1989) 'Learning to teach without teacher education'. Teachers College Record, 91 (2), 191-208.

Guyton, E. and Farokhi, E. (1987) 'Relationships among academic performance, basic skills, subject matter knowledge, and teaching skills of teacher education graduates'. Journal of Teacher Education, 38 (5), 37-42.

Hassabis, D. and Maguire, E.A. (2007) 'Deconstructing episodic memory with construction'. Trends in Cognitive Sciences, 11 (7), 299-306.

Hawk, P.P., Coble, C.R. and Swanson, M. (1985) 'Certification: It does matter'. Journal of Teacher Education, 36 (3), 13-15.

Haydn, T., Arthur, J. and Hunt, M. (2001) Learning to Teach History in the Secondary School: A companion to school experiences. 2 nd ed. London: Routledge.

Herbst, J. (1962) 'The teacher of history'. In Stabler, E. (ed.) The Education of the Secondary School Teacher. Middletown, CT: Wesleyan University Press, 143-63.

Joseph, S. (2003) 'Differential Perceptions of Teachers and Students about the Teaching and Learning of History in Secondary Schools of Trinidad and Tobago'. PhD thesis, Andrews University.

Joseph, S. (2011) 'What are upper secondary school students saying about history?'. Caribbean Curriculum, 18, 1-25.

Johnson-Laird, P.N. (2010) 'Mental models and human reasoning'. Proceedings of the National Academy of Sciences, 107 (43), 18243-50. 
Lasley, T.J. (1980) 'Preservice teacher beliefs about teaching'. Journal of Teacher Education, 31 (4), 38-41.

Lerman, S. (1997) 'The psychology of mathematics teacher learning: In search of theory'. In Pehkonen, E. (ed.) Proceedings of the 21st Conference of the International Group for the Psychology of Mathematics Education (Vol. 3). Helsinki: University of Helsinki, 200-7.

Loewen, J.W. (2007) Lies My Teacher Told Me: Everything your American history textbook got wrong. 2nd ed. New York: Simon and Schuster.

Lortie, D.C. (1975) Schoolteacher: A sociological study. Chicago: University of Chicago Press.

Lortie, D.C. (1977) Schoolteacher: A sociological study. Phoenix ed. Chicago: University of Chicago Press.

Monk, D.H. (1994) 'Subject area preparation of secondary mathematics and science teachers and student achievement'. Economics of Education Review, 13 (2), 125-45.

Nespor, J. (1987) 'The role of beliefs in the practice of teaching'. Journal of Curriculum Studies, 19 (4), 317-28.

Norman, D.A. (1983) 'Some observations on mental models'. In Gentner, D. and Stevens, A.L. (eds) Mental Models. Hillsdale, NJ: Lawrence Earlbaum Associates, 7-14.

Nowicki, J.J. and Meehan, K.F. (1996) The Collaborative Social Studies Classroom: A resource for teachers, grades 7-12. Boston: Allyn and Bacon.

Oppong, C.A. (2009) 'An Evaluation of the Teaching and Learning of History in Senior High Schools in the Central Region of Ghana'. Unpublished MPhil thesis, University of Cape Coast.

Oppong, C.A. (2012) 'Exploring pupils' historical knowledge within the junior high social studies course'. Procedia - Social and Behavioral Sciences, 55, 339-408.

Oppong, C.A. (2014) 'Cognitive and affective characteristics of history students of the University of Cape Coast'. International Journal of Scientific and Research Publications, 4 (10), 1-7.

Oppong, C.A., Adjepong, C. and Kachim, J.U. (2017) 'Crumpling the significant past: Actions and impressions for the "fall" of history'. Journal of Educational Management, 8, 15-45.

Pajares, F. (1993) 'Preservice teachers' beliefs: A focus for teacher education'. Action in Teacher Education, 15 (2), 45-54.

Russell, W.B. (ed.) (2012) Contemporary Social Studies: An essential reader. Charlotte, NC: Information Age Publishing.

Schell, E. and Fisher, D. (2007) Teaching Social Studies: A literacy-based approach. Upper Saddle River, NJ: Pearson Merrill Prentice Hall.

Tabachnick, B.R. and Zeichner, K.M. (1984) 'The impact of the student teaching experience on the development of teacher perspectives'. Journal of Teacher Education, 35 (6), 28-36.

Thomas, J.A., Pedersen, J.E. and Finson, K. (2001) 'Validating the Draw-A-Science-Teacher- Test Checklist (DASTT-C): Exploring mental models and teacher beliefs'. Journal of Science Teacher Education, 12 (4), 295-310.

Tulving, E. (1983) Elements of Episodic Memory. New York: Oxford University Press.

Woolcock, M., Szreter, S. and Rao, V. (2011) 'How and why does history matter for development policy?'. Journal of Development Studies, 47 (1), 70-96.

Young, K.A. (1994) Constructing Buildings, Bridges, and Minds: Building an integrated curriculum through social studies. Portsmouth, NH: Heinemann. 